\title{
The Relationship between Emotional Behavior Characteristics Reported by Parents and Teachers and Language of Korean Mono-cultural and Culturally Diverse Children
}

\author{
Yoonhee Yang, Dongsun Yim \\ Department of Communication Disorders, Ewha Womans University, Seoul, Korea
}

Correspondence: Dongsun Yim, PhD Department of Communication Disorders, Ewha Womans University, 52 Ewhayeodae-gil, Seodamun-gu, Seoul 03760, Korea

Tel: +82-2-3277-6720

Fax: +82-2-3277-2122

E-mail: sunyim@ewha.ac.kr

Received: April 3, 2020

Revised: April 28, 2020

Accepted: May 1, 2020

This work was supported by the Ministry of Education of the Republic of Korea and the National Research Foundation of Korea (NO. NRF-2018S1A3A2075274)

\begin{abstract}
Objectives: The purpose of this study was to investigate whether parents and teachers' reports on emotional behavior characteristics of Korean mono-cultural and culturally diverse children are consistent. We tried to identify whether the strength (prosocial behavior) of emotional behavior characteristics significantly explains their language ability as a protective factor explaining the language ability of culturally diverse-typically developing children (D-TD). Methods: Participants were 18 Korean mono-cultural children (TD 11, LD 7) and 32 culturally diverse children (TD 16, LD 16) aged 4 to 6 years old, and their parents and teachers. Emotional behavior characteristics were measured using the Korean version of the Strength Difficulties Questionnaire (SDQ-Kr), which included the strength of pro-social behavior, and difficulties of hyperactivity, emotional symptoms, behavioral problems, and peer problems. Results: Parent-teacher reports on the emotional behavior of each group of children were consistent, with the exception that parents perceived their children's difficulties higher than teachers in culturally diverse-language delay (D-LD) children. In the Korean mono-cultural children group, the teachers' peer problem report explained the expressive language significantly; whereas in the culturally diverse children group, the parent's hyperactivity report significantly explained the receptive language. In D-TD group, parent's report of prosocial behavior explained receptive language significantly. Conclusion: The importance of parent reports was more significant in culturally diverse children as the parent's report significantly explained the receptive language. In particular, in the case of D-TD group who had normal language ability, it was confirmed that children's prosocial behavior reported by parents could contribute significantly to language ability.
\end{abstract}

Keywords: Culturally diverse children, Parent-teacher reports, Strength and Difficulties Questionnaire (SDQ-Kr), Prosocial behavior, Language ability
다문화 가정의 아동 또는 이민자, 소수민족 아동들의 발달에 불 리한 영향을 미칠 수 있는 요인으로 낮은 사회경제적 요인, 자아개 념(self-concept), 자존감(self-esteem) 등이 선행연구에서 다수 보 고되어왔다(Atzaba-Poria, Pike, \& Deater-Deckard, 2004; Thijs \& Verkuyten, 2017). 우리나라에서도 마찬가지로 2018년 전국 다문화 가족 실태조사에 따르면, 다문화 가족의 일원으로 자긍심을 갖지 못하는 자녀들은 약 $56.8 \%$ 로, 전반적으로 성, 연령, 출신국적, 성장
배경에 관계없이 우리나라에 거주하는 다문화 가족 자녀들의 다문 화 가족으로서의 자긍심이 전반적으로 높지 않다고 보고된다(Choi, et al., 2019). 또한, 다문화 가정의 아동은 단일문화 가정의 아동에 비해 사회 정서적 능력이 낮다고 보고되며, 이는 낮은 언어능력, 가 정의 낮은 사회 경제적 여건, 한국문화에 적응하기 위한 스트레스 등이 상호작용한 결과임을 밝혔다(Byun \& Son, 2011). 의사소통 상의 어려움을 경험하는 다문화 아동들은 정서 및 행동에서도 어 
려움을 경험할 수 있으며, 사회적 갈등 맥락에서 적절한 문제해결능 력을 보이는 능력이 높은 언어능력과 관련된다고 보고되기도 한다 (Zadeh, Im-Bolter, \& Cohen, 2007). 또한, 이민자 출신 학생들이 정 서행동의 모든 측면에서 매우 불안정한 발달을 보이기도 했는데, 이 들의 사회적 정서행동을 증진시켰을 때의 긍정적 효과는 학령전기 에 경제적으로 어려움을 겪고 있었으나 사회의 언어인 영어 사용능 력이 부족하지 않았던 학생들에게 나타났다(Sung, 2014). 이를 통해 가정의 사회경제적 지위보다도 아동의 언어능력이 정서행동 특성 과 더 긴밀한 연관성을 나타낼 가능성에 대해 추론해볼 수 있다.

이처럼 아동들의 정서행동 특성은 크게 긍정적 특성과 부정적 특성의 두 가지 중요한 측면으로 나누어질 수 있는데, 효과적 관계 맺기에 필요한 사회지향행동은 긍정적 특성으로 분류되고, 부정적 특성으로는 내재화 문제인 정서증상, 외현화 문제인 과잉행동, 행동 문제, 또래문제 등이 포함된다(Goodman, 1997; Montroy, Bowles, Skibbe, \& Foster, 2014; Rose-Krasnor, 1997). 이러한 정서행동 특성 은 지속적으로 언어와 학업성취 등과 관련이 있는 것으로 알려져 있다(Im \& Jeong, 2010; Lee \& Oh, 2019; O’Kearney \& Goh, 2012; Valiente et al., 2011). 즉, 긍정적 정서행동 특성인 사회지향행동은 언어습득 및 학업성취에도 도움이 될 수 있으며, 부정적 정서행동 특성인 정서증상, 과잉행동, 행동문제, 또래문제 등은 언어습득 및 학업성취를 방해하는 요소가 될 수 있음을 추론해볼 수 있다. 실제 로 언어발달이 지연된 아동들은 또래 일반아동에 비해 정서행동 문제를 지니기 쉬운데, 이들이 의사소통에서 어려움을 경험하는 것이 타인과 관계 맺기를 어렵게 만들고, 자신의 요구와 감정을 표 현하는 것과 타인으로부터의 메시지를 이해하는 것의 어려움이 좌 절과 고통을 유발하기 때문이다(Brinton \& Fujiki, 1993, 2010; Fujiki, Brinton, \& Clarke, 2002; Ketelaars, Cuperus, Jansonius, \& Verhoeven, 2010; Lindsay, Dockrell, \& Strand, 2007; Tomblin, Zhang, Buckwalter, \& Catts, 2000).

정서행동 특성과 언어능력은 서로 밀접한 관련이 있는 것으로 보 인다. 만약, 아동이 부주의, 과잉행동, 반항행동과 같은 외현화 행 동문제를 많이 보인다면, 이 문제행동이 언어 결함과도 유의한 상 관관계를 보인다고 보고되었다(Campbell, Shaw, \& Gilliom, 2000; Lonigan et al., 1999). Bulotsky-Shearer, Dominguez와 Bell (2012) 은 사회적 위축행동이 낮은 언어능력과 관련된다고 하였으며, 특 히, 부족한 수용언어 능력을 지닌 경우 더 많은 정서행동 문제를 나 타낸다고 하였다. Adams, Snowling, Hennessy 그리고 Kind (1999) 는 강점 난점 설문지(SDQ; Strengths and Difficulties Questionnaire; Goodman, 1997)를 통해 '과잉행동(Hyperactive)'의 평가를 받은 아동은 언어적 핵심기술에서도 또래에 비해 저조한 수행을 보
였다고 보고하였다. 또한, 행동문제의 비율이 높은 어린 아동은 명 백히 언어능력에서 결함을 보였다(Speltz, DeKlyen, Calderon, Greenberg, \& Fisher, 1999). 이처럼 초기 문제행동이 언어 결함과 관련되 어 있음이 다수의 선행연구를 통해 보고되어 왔다(Hughes \& Ensor, 2008).

이처럼 주로 아동의 정서행동상의 어려움과 언어문제의 관련성에 대해 보고한 선행연구가 다수 존재한다(O’Kearney \& Goh, 2012; Valiente et al., 2011). 특히, 선행연구에서 사용한 정서행동 특성 측 정 도구는 아동 행동 체크리스트(CBCL, Child Behavior Checklist)와 같이 문제행동 또는 외현화 행동문제를 주로 기술한 것이 많 다(Achenbach et al., 2008; Valiente et al., 2011). 그러나, 강점 난점 설문지(SDQ)는 정서행동상의 난점뿐만 아니라 강점까지도 확인 할 수 있으며, 약 30 개 언어로 번역되어 전세계적으로 널리 사용되 고, 부모 또는 교사가 5 분 이내로 작성할 수 있을 만큼 간결하고 효 율적인 특징이 있다. 부정적인 정서행동 특성이 언어능력과 부적 상관관계를 지닐 수 있는 만큼, 긍정적 정서행동 특성인 사회지향 행동은 아동들의 언어능력과 정적으로 관련될 수 있어 이를 살펴 보기에 적합하다(Bagwell, Newcomb, \& Bukowski, 1998; Campbell et al., 2000; St Clair, Pickles, Durkin, \& Conti-Ramsden, 2011).

또한, 영유아기에는 아동이 주로 가족과 관계를 맺지만, 아이가 성장하여 어린이집이나 유치원과 같은 사회적 집단에 속하게 되면 아동의 관계망은 또래 및 교사로 확대된다. 이 시기의 또래관계는 아동과 가족 구성원의 관계, 혹은 아동과 교사의 관계와는 대조적 으로 상호성과 동등성을 기초로 하여 자발적으로 맺어진 관계이다 (Hartup, 1992). 선행 연구에 따르면, 친밀하고 지지적인 또래관계 를 형성한 아동들은 사회적 집단에서의 생활이 즐겁다고 느끼고, 높은 성취를 보일 뿐만 아니라 학교 적응력과 사회정서적 능력이 좋은 것으로 나타났다(Coolahan, Fantuzzo, Mendez, \& McDermott, 2000). 반면, 또래로부터 수용 받지 못하거나 거부당하는 등 부정적인 또래관계를 형성한 아동들은 공격적 행동을 보이거나 외 로움, 우울감 등의 심리적 문제, 폭력의 피해 등으로 기관에서의 생 활에 적응하지 못하거나 성장하면서 부정적인 성격이 형성되어 원 만한 대인관계를 맺지 못하거나, 반사회적 문제를 보이는 성인이 될 가능성이 높았다(Bagwell et al., 1998). 이처럼 아동의 관계 맺기가 가족구성원에서 또래 및 교사로 확대되는 학령전기 및 학령기에는 부모와 교사의 보고를 함께 받기도 한다. 국내에서는 Lee와 Choi (2012)의 연구에서 만 3-5세 다문화 가정 유아 189명을 대상으로 보호요인과 행동문제에 대한 부모와 교사의 평가를 비교한 결과, 다문화 가정의 부모가 교사보다 전반적으로 자녀에 대해 부정적으 로 평가하는 경향이 있었다. Kim, Ahn과 Kim (2012)은 한국어판 
강점 난점 설문지(SDQ-Kr)와 아동, 청소년 행동평가척도(K-CB$\mathrm{CL}$ )를 통해 6-12세 아동의 부모와 교사의 보고를 비교한 결과, 모 든 척도에서 높은 상관이 나타났음을 보고하였다. 즉, 아동은 가정 과 학교 등 평가되는 장소와 환경에 따라 다양한 정서행동 특성을 나타낼 수 있지만, 아동에 대해 높은 이해와 많은 관심을 가진 부 모-교사 간 평가의 일관성이 나타난다면 아동의 정서행동 특성에 대한 보고의 신뢰도를 더욱 높여줄 수 있다.

Conti-Ramsden, Mok, Pickles 그리고 Durkin (2013)의 연구에 서는 16 세의 단순언어장애(Specific language impairment; SLI) 이 력을 지닌 139명, 또래 일반아동(Typically developing children; $\mathrm{TD}) 124$ 명을 대상으로 강점 및 난점 설문지(SDQ)를 사용하여 정 서행동 특성을 살펴본 결과, SLI 아동이 또래 TD 아동에 비해 또래 문제를 더 많이 경험하였고, 정서증상, 과잉행동, 행동문제가 더 많 았음을 보고하였다. 그러나, SLI 집단과 TD 집단 중 대다수의 청소 년들은(SLI 87\%, TD 96\%) 정상 범주 내의 사회지향행동, 즉, 친 사 회적 행동을 나타내어 도움주기, 공유하기 등 타인에게 이로움을 주려고 하는 강점에서보다 난점(특히, 또래문제)에서 두 집단의 차 이가 더 크게 나타남을 알 수 있다(St Clair et al., 2011; Durkin \& Conti-Ramsden, 2007). Hart, Fujiki, Brinton 그리고 Hart (2004) 의 연구에서는 교사 보고를 통해 단순언어장애(SLI) 아동들의 사 회적 행동에 대해 확인한 결과, 교사들이 SLI 아동에 대해 TD 아 동에 비해 더 과묵하고, 사회적 행동을 덜 보인다고 평가하였음을 확인하였다. 특히, 언어표현에 심각한 문제가 있는 아동들은 더 부 족한 사회적 행동을 보였다.

그러나, 다문화 아동 중 상당수는 또래 단일문화 아동과 비교했 을 때 내면화 및 외현화 문제, 심리사회적 적응, 언어발달 등에서 유 의한 차이를 보이지 않는 것으로 보고되기도 한다(Kim, \& Hong, 2017). 이는 다문화 가정 자녀를 둘러싼 위험요인을 완화시켜주는 보호요인이 존재함을 의미한다. 다문화 가정의 아동들을 둘러싼 사회·문화적, 언어적 환경에 의하면 다양한 위험요인이 산재해 있 고, 양질의 언어능력을 갖추기에도 또래 단일문화 아동에 비해 상 대적인 불리함을 지니고 있지만, 결국 좋은 언어능력이 그들을 문 화적 편견과 차별로부터 자유롭게 해줄 수 있다. 따라서 이들이 좋 은 언어능력을 갖출 수 있게 돕는 것은 필수적인 과업이며, 다문화 가족 및 아동에 대한 배타적 시선과 편견, 보이지 않는 교육의 불평 등, 사회경제적 자산에 대한 접근의 제한 등 상대적으로 다양한 위 험요인들을 확인하고 최소화할 수 있는 방안을 모색함과 동시에 더불어 이들을 보호해줄 수 있는 보호요인에 대한 접근이 이루어 져야 한다. 또한, 이들이 불리한 언어습득 맥락 속에서 성장함에도 불구하고 정상 언어발달 범주에 속해 있다면, 이들의 잔존하는 언
어능력을 설명해줄 보호요인이 존재할 것으로 추론해볼 수 있다. 이에 본 연구에서는 다문화 아동 집단을 언어발달지연 아동 $(\mathrm{Cul}-$ turally diverse children with language delay, D-LD)과 언어능력이 평균 범주에 속하는 일반 아동(Culturally diverse typically developing children, D-TD)으로 나누고, 또래 한국 단일문화아동 집단 (일반, 언어발달지연)과 비교하여 정서행동 특성에 대한 부모-교사 의 보고가 일치하는지, 집단 간 차이가 유의한지 살펴보고, 다문화 및 단일문화 아동 집단 각각의 언어능력과 가장 상관이 높고 강력 한 설명력을 지닌 정서행동 특성(부모 또는 교사의 보고)은 무엇인 지 확인하고자 하였으며, 궁극적으로는 다문화 아동 집단 중 언어 능력이 잔존하는 일반 아동(D-TD) 집단의 경우 교사 또는 부모의 보고 중 정서행동 특성에서의 강점이 이들의 언어능력을 가장 잘 설명하는지 확인하고자 하였다.

이에 대한 세부적인 연구질문은 다음과 같다.

1. 다문화 아동 집단(D-TD, D-LD) 및 또래 한국 단일문화 아동 집단(K-TD, K-LD)의 정서행동 특성에 대한 부모-교사의 보고 는 일치하는가?

2. 다문화아동 집단(D-TD, D-LD) 및 또래 한국 단일문화아동 집 단(K-TD, K-LD)의 정서행동 특성은 집단 간차이가 유의한가?

3. 다문화 아동 $(\mathrm{D})$ 및 또래 한국 단일문화 아동(K) 집단, 그리고 D-TD, D-LD, K-TD, K-LD 각각에서 언어능력과 정서행동 특 성은 유의한 상관관계를 보이는가?

4. 다문화 아동 $(\mathrm{D})$ 및 또래 한국 단일문화 아동 $(\mathrm{K})$ 집단, 그리고 D-TD, D-LD, K-TD, K-LD 각각에서 교사 또는 부모의 보고 중 어떤 정서행동 특성 보고가 언어능력을 가장 잘 설명하는 가? 그 중, 다문화 일반아동(D-TD) 집단의 경우 교사 또는 부 모의 보고 중 정서행동 특성의 강점이 이들의 언어능력을 유의 하게 설명하는가?

\section{연구방법}

\section{연구대상}

본 연구는 만 4-6세 한국 단일문화 일반 아동(Korean typically developing children, K-TD) 11명, 한국 단일문화 언어발달지연 아 동(Korean children with language delay, K-LD) 7명, 다문화 일반 아동(Culturally diverse typically developing children, D-TD) 16명, 다문화 언어발달지연 아동(Culturally diverse children with language delay, D-LD) 16 명, 총 50 명을 대상으로 하였다. 언어장애의 유무를 확인하기 위해 전문가의 언어검사결과에만 의존하는 것으 로는 충분하지 않을 수 있으므로 주양육자의 보고를 통해 보완하 
여야 한다는 선행연구에 근거하여 표준화검사도구(Receptive \& Expressive Vocabulary Test, REVT; Kim, Hong, Kim, Jang, \& Lee, 2009)뿐만 아니라 부모보고(Korean Brief Parent Report, KBPR; Han \& Yim, 2018)를 함께 받았다(Bishop \& McDonald, 2009). $\mathrm{KBPR}$ 은 공인타당도와 신뢰도(Cronbach's $\alpha=.827$ )가 검증된 바 있다(Han \& Yim, 2018).

한국 단일문화 일반 아동(K-TD)은 (1) 부모가 모두 한국인으로 한국에서 출생하였으며 가정 및 교육기관에서 한국어를 유창하게 구사하는 아동으로, (2) 한국어판 카우프만 아동용 지능검사 $(\mathrm{K}-$ $\mathrm{ABC}$, Moon \& Byun, 2003)의 비언어성 척도에서 85점(-1 SD) 이상 으로 정상 발달 범주에 속하며, (3) 취학 전 아동의 수용언어 및 표 현언어 척도(PRES; Kim, Sung, \& Lee, 2003) 결과 수용언어 및 표 현언어 점수가 모두 -1 SD 이상, (4) 수용·표현어휘력 검사(REVT; Kim et al., 2009) 결과 수용 어휘 및 표현 어휘 점수가 모두 -1 SD 이 상, (5) 부모 보고형 아동 언어 능력 평가도구(KBPR, Han \& Yim, 2018)를 통해 부모로부터 아동의 현재 언어발달에 문제가 없는 것 으로 보고되고, (6) 주양육자 또는 교사에 의해 임상적 수준의 감각 (시청각), 정서 및 행동, 운동발달의 이상을 보이지 않는 아동을 연 구대상으로 하였다.

한국 단일문화 언어발달지연 아동(K-LD)은 (1) 부모가 모두 한 국인으로 한국에서 출생하였으며 가정 및 교육기관에서 한국어를 유창하게 구사하는 아동으로, (2) 한국어판 카우프만 아동용 지능 검사(K-ABC; Moon \& Byun, 2003)의 비언어성 척도에서 85점(-1 $\mathrm{SD}$ ) 이상으로 정상 발달 범주에 속하며, (3) 취학 전 아동의 수용언 어 및 표현언어 척도(PRES; Kim et al., 2003) 결과 수용언어 또는 표현언어 점수가 - $1.25 \mathrm{SD}$ 미만, (4) 수용·표현 어휘력 검사(REVT; Kim et al., 2009) 결과 수용 어휘 또는 표현 어휘 점수가 - $1.25 \mathrm{SD}$ 미 만, (5) 부모 보고형 아동 언어 능력 평가도구(KBPR, Han \& Yim, 2018)를 통해 부모로부터 아동의 현재 언어발달에 문제가 있는 것 으로 보고되며, (6) 주양육자 또는 교사에 의해 언어발달지연에 대 한 보고를 받았으나 임상적 수준의 감각(시청각), 정서 및 행동, 운 동발달의 이상을 보이지 않는 아동을 연구대상으로 하였다.

다문화 일반 아동(D-TD)은 (1) 결혼이민자 및 귀화자 등과의 사 이에서 한국에서 출생하여 한국어를 제 1 언어로 사용하는 아동으로, (2) 한국어판 카우프만 아동용 지능검사(K-ABC; Moon \& Byun, 2003)의 비언어성 척도에서 85점(-1 SD) 이상으로 정상 발달 범주 에 속하며, (3) 취학 전 아동의 수용언어 및 표현언어 척도(PRES; Kim et al., 2003) 결과 수용언어 및 표현언어 점수가 모두 -1 SD 이 상, (4) 수용·표현 어휘력 검사(REVT; Kim et al., 2009) 결과 수용 어휘 및 표현 어휘 점수가 모두 -1 SD 이상, (5) 부모 보고형 아동 언
어 능력 평가도구(KBPR; Han \& Yim, 2018)를 통해 부모로부터 아 동의 현재 언어발달에 문제가 없는 것으로 보고되고, (6) 주양육자 또는 교사에 의해 임상적 수준의 감각(시청각), 정서 및 행동, 운동 발달의 이상을 보이지 않는 아동을 연구대상으로 하였다.

다문화 언어발달지연(D-LD) 아동은 (1) 결혼이민자 및 귀화자 등과의 사이에서 한국에서 출생하여 한국어를 제 1 언어로 사용하 는 아동으로, (2) 한국어판 카우프만 아동용 지능검사(K-ABC; Moon \& Byun, 2003)의 비언어성 척도에서 85점(-1 SD) 이상으로 정상 발달 범주에 속하며, (3) 취학 전 아동의 수용언어 및 표현언어 척도(PRES; Kim et al., 2003) 결과 수용언어 또는 표현언어 점수가 -1.25 SD 미만, (4) 수용·표현 어휘력 검사(REVT; Kim et al., 2009) 결과 수용 어휘 또는 표현 어휘 점수가 - $1.25 \mathrm{SD}$ 미만, (5) 부모 보고 형 아동 언어 능력 평가도구(KBPR; Han \& Yim, 2018)를 통해 부 모로부터 아동의 현재 언어발달에 문제가 있는 것으로 보고되며, (6) 주양육자 또는 교사에 의해 언어발달지연에 대한 보고를 받았 으나 임상적 수준의 감각(시청각), 정서 및 행동, 운동발달의 이상 을 보이지 않는 아동을 연구대상으로 하였다.

연구참여 아동 가정의 사회경제적지위(socio economic statues, $\mathrm{SES}$ )를 확인하기 위해 아동 아버지의 교육연수, 어머니의 교육연수 를 조사하였으며, 다문화가정 아동 어머니의 출신국적을 확인하였 다. 아버지의 교육연수의 평균은 K-TD 아동의 아버지의 경우 15.82 년(SD = 1.662), K-LD 아동 아버지는 15.00 년(SD = 2.517), D-TD 아 동 아버지는 12.69 년(SD $=1.887), \mathrm{D}-\mathrm{LD}$ 아버지는 12.73 년(SD = 1.944)이었다. 사후분석(Bonferroni) 실시 결과, K-TD 집단의 아버 지는 D-TD, D-LD 집단 아버지의 교육연수에 비해 유의하게 높았 다 $(p<.01)$. 어머니 교육연수의 평균은 K-TD 아동의 어머니의 경우 15.64 년(SD = 1.206), K-LD 아동의 어머니는 15.29 년(SD = 2.360), $\mathrm{D}-\mathrm{TD}$ 아동의 어머니는 12.25 년(SD = 2.793), D-LD 아동의 어머니 는 10.71년(SD=3.646)이었다. 사후분석(Bonferroni) 실시 결과, $\mathrm{K}-\mathrm{TD}$ 집단의 어머니는 D-TD $(p<.05), \mathrm{D}-\mathrm{LD}(p<.01)$ 집단 어머니 의 교육연수에 비해 유의하게 높았으며, K-LD 집단의 어머니는 $\mathrm{D}-\mathrm{LD}$ 집단 어머니의 교육연수에 비해 유의하게 높았다 $(p<.01)$. 어 머니 국적은 D-TD 집단 내에서 베트남 7명(43.75\%), 중국 6명(37.50\%), 필리핀 2명(12.50\%), 기타 1명(6.25\%)이었으며, D-LD 집단 내에서 베트남 9명(56.25\%), 중국 3명(18.75\%), 필리핀 2명(12.50\%), 캄보디 아 1 명(6.25\%), 기타 1 명(6.25\%)이었다. 세부내용은 Table 1에 제시 하였다.

아동의 연령은 네 집단 간 유의한 차이가 없었다 $\left(F_{(3,49)}=.770\right.$, $p=.516)$. 아동의 수용언어능력은 $\mathrm{K}-\mathrm{TD}$ 집단 52.36점( $\mathrm{SD}=7.15)$, $\mathrm{K}-\mathrm{LD}$ 집단 42.29 점 $(\mathrm{SD}=10.63), \mathrm{D}-\mathrm{TD}$ 집단 43.13 점 $(\mathrm{SD}=9.71)$, 
Table 1. Parent's characteristics

\begin{tabular}{|c|c|c|c|c|c|}
\hline Variables & $\mathrm{K}-\mathrm{TD}(\mathrm{N}=11)$ & $\mathrm{K}-\mathrm{LD}(\mathrm{N}=7)$ & $\mathrm{D}-\mathrm{TD}(\mathrm{N}=16)$ & $D-L D(N=16)$ & Post-hoc \\
\hline \multicolumn{6}{|l|}{ SES } \\
\hline Father's education & 15.82 (1.662) & $15.00(2.517)$ & $12.69(1.887)$ & $12.73(1.944)$ & $\begin{array}{l}\mathrm{K}-\mathrm{TD}>\mathrm{D}-\mathrm{TD}^{* *} \\
\mathrm{~K}-\mathrm{TD}>\mathrm{D}-\mathrm{LD}^{* *}\end{array}$ \\
\hline Mother's education & 15.64 (1.206) & $15.29(2.360)$ & $12.25(2.793)$ & 10.71 (3.646) & $\begin{array}{l}\mathrm{K}-\mathrm{TD}>\mathrm{D}-\mathrm{TD}^{*} \\
\mathrm{~K}-\mathrm{TD}>\mathrm{D}-\mathrm{LD}^{* *} \\
\mathrm{~K}-\mathrm{LD}>\mathrm{D}-\mathrm{LD}^{* *}\end{array}$ \\
\hline \multicolumn{6}{|l|}{ Mother's nationality } \\
\hline Korea & $100 \%$ & $100 \%$ & $0 \%$ & $0 \%$ & \\
\hline Vietnam & $0 \%$ & $0 \%$ & $43.75 \%$ & $56.25 \%$ & \\
\hline China & $0 \%$ & $0 \%$ & $37.50 \%$ & $18.75 \%$ & \\
\hline Philippine & $0 \%$ & $0 \%$ & $12.50 \%$ & $12.50 \%$ & \\
\hline Cambodia & $0 \%$ & $0 \%$ & $0 \%$ & $6.25 \%$ & \\
\hline Etc. & $0 \%$ & $0 \%$ & $6.25 \%$ & $6.25 \%$ & \\
\hline
\end{tabular}

Values are presented as mean (SDs).

$\mathrm{K}-\mathrm{TD}=$ Korean typically developing children; $\mathrm{K}-\mathrm{LD}=$ Korean children with language delay; $\mathrm{D}-\mathrm{TD}=$ Culturally diverse typically developing children; $\mathrm{D}-\mathrm{LD}=\mathrm{Culturally}$ diverse children with language delay.

${ }^{*} p<.05,{ }^{* *} p<.01$.

Table 2. Children's' characteristics

\begin{tabular}{|c|c|c|c|c|c|}
\hline Variables & $\mathrm{K}-\mathrm{TD}(\mathrm{N}=11)$ & $\mathrm{K}-\mathrm{LD}(\mathrm{N}=7)$ & $\mathrm{D}-\mathrm{TD}(\mathrm{N}=16)$ & $\mathrm{D}-\mathrm{LD}(\mathrm{N}=16)$ & Post-hoc \\
\hline Age & $67.36(2.04)$ & $67.86(2.01)$ & $64.19(7.14)$ & $64.00(9.60)$ & - \\
\hline Receptive language $^{a}$ & $52.36(7.15)$ & $42.29(10.63)$ & $43.13(9.71)$ & $38.63(7.21)$ & $\mathrm{K}-\mathrm{TD}>\mathrm{D}-\mathrm{LD} \mathrm{D}^{* *}$ \\
\hline Expressive language $^{\mathrm{a}}$ & $49.27(5.39)$ & $40.14(9.06)$ & $41.81(4.86)$ & $33.75(7.60)$ & $\begin{array}{l}\text { K-TD }>\text { K-LD* } \\
\text { K-TD }>\text { D-TD* } \\
\text { K-TD }>\text { D-LD** } \\
\text { D-TD }>\text { D-LD** }\end{array}$ \\
\hline Receptive vocabulary ${ }^{b}$ & $68.82(7.59)$ & $54.00(14.70)$ & $56.88(11.61)$ & 39.69 (15.86) & $\begin{array}{l}\mathrm{K}-\mathrm{TD}>\mathrm{D}-\mathrm{LD}^{* *} \\
\mathrm{D}-\mathrm{TD}>\mathrm{D}-\mathrm{LD}^{* *}\end{array}$ \\
\hline Expressive vocabulary & $69.18(11.57)$ & $57.71(13.05)$ & 59.50 (6.02) & $43.25(15.81)$ & $\begin{array}{l}\mathrm{K}-\mathrm{TD}>\mathrm{D}-\mathrm{LD}^{* *} \\
\mathrm{D}-\mathrm{TD}>\mathrm{D}-\mathrm{LD}^{* *}\end{array}$ \\
\hline Language ability (parent report) $^{c}$ & $12.64(1.69)$ & $9.43(3.69)$ & $10.75(2.11)$ & $8.38(2.47)$ & $\begin{array}{l}\mathrm{K}-\mathrm{TD}>\mathrm{D}-\mathrm{LD}{ }^{* *} \\
\mathrm{D}-\mathrm{TD}>\mathrm{D}-\mathrm{LD}\end{array}$ \\
\hline
\end{tabular}

Values are presented as mean (SDs).

$\mathrm{K}-\mathrm{TD}=$ Korean typically developing children; $\mathrm{K}-\mathrm{LD}=$ Korean children with language delay; $\mathrm{D}-\mathrm{TD}=$ Culturally diverse typically developing children; $\mathrm{D}-\mathrm{LD}=\mathrm{Culturally}$ diverse children with language delay.

aPreschool Receptive \& Expressive Language Scale (PRES; Kim, Sung, \& Lee, 2003), 'beceptive and Expressive Vocabulary Test (REVT; Kim, Hong, Kim, Jang, \& Lee, 2009), 'cKorean Brief Parent Report (KBPR; Han \& Yim, 2018).

${ }^{*} p<.05,{ }^{* *} p<.01$.

$\mathrm{D}-\mathrm{LD}$ 집단 38.63점 $(\mathrm{SD}=7.21)$ 이었다. 사후분석(Bonferroni) 실시 결과, K-TD 집단의 수용언어는 D-LD 집단에 비해 유의하게 높았 다 $(p<.01)$. 아동의 표현언어능력은 K-TD 집단 49.27점 $(\mathrm{SD}=5.39)$, $\mathrm{K}-\mathrm{LD}$ 집단 40.14 점 $(\mathrm{SD}=9.06), \mathrm{D}-\mathrm{TD}$ 집단 41.81 점 $(\mathrm{SD}=4.86)$, $\mathrm{D}-\mathrm{LD}$ 집단 33.75점 $(\mathrm{SD}=7.60)$ 이었다. 사후분석(Bonferroni) 실시 결과, $\mathrm{K}-\mathrm{TD}$ 집단의 표현언어는 $\mathrm{K}-\mathrm{LD}$ 점 $(p<.05), \mathrm{D}-\mathrm{TD}(p<.05)$, $\mathrm{D}-\mathrm{LD}(p<.01)$ 집단에 비해 유의하게 높았고, D-TD 집단의 표현언 어도 D-LD 집단에 비해 유의하게 높았다 $(p<.01)$. 아동의 수용 어 휘능력은 K-TD 집단 68.82 점 $(\mathrm{SD}=7.59)$, K-LD 집단 54.00 점(SD =
14.70), D-TD 집단 56.88점(SD = 11.61), $\mathrm{D}-\mathrm{LD}$ 집단 39.69점( $\mathrm{SD}=$ 15.86)이었다. 사후분석(Bonferroni) 실시 결과, K-TD 집단의 수용 어휘는 D-LD 집단에 비해 유의하게 높았고 $(p<.01), \mathrm{D}-\mathrm{TD}$ 집단의 수용 어휘도 D-LD 집단에 비해 유의하게 높았다 $(p<.01)$. 아동의 표현 어휘능력은 K-TD 집단 69.18점( $\mathrm{SD}=11.57), \mathrm{K}-\mathrm{LD}$ 집단 57.71 점 $(\mathrm{SD}=13.05), \mathrm{D}-\mathrm{TD}$ 집단 59.50 점 $(\mathrm{SD}=6.02), \mathrm{D}-\mathrm{LD}$ 집단 43.25 점 $(\mathrm{SD}=15.81)$ 이었다. 사후분석(Bonferroni) 실시 결과, K-TD 집단의 표현 어휘는 D-LD 집단에 비해 유의하게 높았고 $(p<.01), \mathrm{D}-\mathrm{TD}$ 집 단의 표현 어휘도 D-LD 집단에 비해 유의하게 높았다 $(p<.01)$. 부 
모가 보고한 아동의 현재 언어능력은 K-TD 집단 12.64 점 $(\mathrm{SD}=1.69)$, $\mathrm{K}-\mathrm{LD}$ 집단 9.43점 $(\mathrm{SD}=3.69), \mathrm{D}-\mathrm{TD}$ 집단 10.75점 $(\mathrm{SD}=2.11), \mathrm{D}-\mathrm{LD}$ 집단 8.38점 $(\mathrm{SD}=2.47)$ 이었다. 사후분석(Bonferroni) 실시 결과, K-TD 집단의 현재언어능력은 D-LD 집단에 비해 유의하게 높았고 $(p<.01), \mathrm{D}-\mathrm{TD}$ 집단의 현재언어능력도 D-LD 집단에 비해 유의하 게 높았다( $p<.05)$. 아동의 언어능력에 대한 세부적인 내용은 Table 2에 제시하였다.

\section{연구변인}

\section{한국어판 강점 난점 설문지(SDQ- $\mathrm{Kr})$}

본 연구에서는 아동의 정서행동 특성을 측정하기 위해 한국어 판 강점 난점 설문지(The strengths and difficulties questionnaire, SDQ-Kr; Ahn, Jun, Han, Noh, \& Goodman, 2003)를 사용하였다. 한국어판 강점 난점 설문지(SDQ-Kr)는 Goodman (1997)의 설문 지를 한국어로 번역한 것으로 만 4-16세 아동 및 청소년의 심리적 적응(psychological adjustment)을 측정하는 도구이다. SDQ는 약 30 개 이상의 언어로 제공되며, 임상 및 발달 연구뿐만 아니라 교육 분야에서도 널리 사용되고 있다(Goodman \& Scott, 1999). SDQ는 아동의 부모 또는 교사가 5 분 이내로 간단하게 실시할 수 있으며, 기존의 다른 정서행동측정도구(예: $\mathrm{CBCL}$ )가 아동의 난점에만 주 로 초점을 맞추었던 것과 달리, 아동의 사회 정서행동적 강점에도 주목한다는 장점을 지닌다. 강점을 측정하는 '사회지향행동(prosocial behavior)'은 다른 사람들을 돌보고, 공유하고, 돕는 특성을 측정하는 것으로, $1,4,9,17,20$ 번 문항이 해당된다. 난점은 4 개의 하위요소로 구성되어 있으며, 그 중 '과잉행동(hyperactivity)'은 오 랫동안 가만히 있지 못하거나 산만한 특성 등을 측정하는 것으로 $2,10,15,21,25$ 번 문항이 해당되고, 21,25 번 문항은 역 채점한다. '정서증상(emotional symptom)'은 우울, 불안과 같은 내면화 증상 을 포함하는 것으로 $3,8,13,16,24$ 번 문항이 해당된다. '행동문제 (conduct problem)'는 청소년기의 반사회적 행동과도 긴밀하게 연 관되는 가장 흔한 외현화 문제로 $5,7,12,18,22$ 번 문항이 해당되며, 7번 문항은 역 채점한다. '또래 문제(peer problem)'는 또래에게 거 부되는 경험을 포함한 또래관련 문제를 포함하고 $6,11,14,19,23$ 번 문항이 해당되며 11,14 번 문항은 역 채점한다.

강점은 사회지향행동(5문항), 난점은 과잉행동(5문항), 정서증 상(5문항), 행동문제(5문항), 그리고 또래문제(5문항), 총 25 문항으 로 구성되어 있다. SDQ-Kr을 사용하여 부모가 보고하였을 때의 신뢰도를 확인한 결과, 검사-재검사 신뢰도는 사회지향행동 .88 , 과 잉행동 .92 , 정서증상 .84 , 행동문제 .94 , 또래문제 .89로 보고되었다 (Ahn et al., 2003). 내적 일치도(internal consistency)를 나타내는
Cronbach's alpha 계수는 사회지향행동 .65 , 과잉행동 .80, 정서증 상 .61, 행동문제 .50, 또래문제 .63이었다(Ahn et al., 2003). 감별 타 당도 확인 결과, 모든 영역에서 비 임상군과 임상군을 유의하게 구 분해주는 것으로 나타났다(Ahn et al., 2003).

$\mathrm{SDQ}-\mathrm{Kr}$ 은 총 5 가지 세부영역으로 구성되어 있으며, 본 연구에 서는 강점에 속하는 사회지향행동(prosocial behavior) 5 문항, 난점 에 속하는 과잉행동(hyperactivity) 5 문항, 정서증상(emotional symptom) 5 문항, 행동문제(conduct problem) 5 문항, 또래문제(peer problem) 5 문항, 총 25 문항을 통해 아동의 정서행동능력을 평가하는 설 문지이다. 평정은 3점 척도('전혀 아니다', '다소 그렇다', '분명히 그 렇다')로 이루어져 있으며, 문항 당 0-2점으로 채점한다. 문항에 따 라 ‘전혀 아니다'가 2점이 될 수도 있고, 0 점이 될 수도 있다. 강점의 총점은 10 점, 난점의 총점은 40 점이며 강점은 높을수록 바람직하 고, 난점은 낮을수록 바람직하다(Ahn et al., 2003). 설문지 양식은 Appendix 1에 제시하였다.

\section{취학 전 아동의 수용언어 및 표현언어 척도(PRES)}

본 연구에서는 연구대상 아동들의 전반적인 언어능력을 확인하 기 위해 취학 전 아동의 수용언어 및 표현언어 척도(Preschool Receptive-Expressive Language Scale, PRES; Kim et al., 2003)를 사 용하였다. PRES는 아동의 언어 이해와 표현 영역을 모두 검사할 수 있는 표준화 검사 도구로 언어발달수준이 2-6세에 해당하는 아동 들의 수용 및 표현언어능력을 측정할 수 있다. 특히, 이 도구는 언어 의 의미론, 구문론, 화용론적 측면을 고루 포함하고 있어 전반적인 언어발달 영역에서의 수준을 평가하기에 적합한 도구이다.

\section{자료분석 및 결과처리}

네 집단(K-TD, K-LD, D-TD, D-LD) 각각에서의 정서행동 특성 에 대해 부모-교사간 평정의 일치 여부를 확인하기 위해 각 집단 케 이스를 선택하여 대응표본 $t$ 검정을 실시하였으며, 네 집단(K-TD, $\mathrm{K}-\mathrm{LD}, \mathrm{D}-\mathrm{TD}, \mathrm{D}-\mathrm{LD})$ 의 정서행동 특성의 차이를 살펴보기 위해 분 산분석(ANOVAs)을 실시하였다. 특히, 정서행동 특성 중 난점의 경우, 삼원혼합분산분석(three-way mixed ANOVA)을 실시하였으 며, 집단(4: K-TD, K-LD, D-TD, D-LD) × 보고자(2: Parent, Teacher) $\times$ 난점 하위유형(4: Hyperactivity, Emotional symptom, Conduct problem, Peer problem)에 따른 결과를 분석하였다. 사후분석 은 Bonferroni 사후검정을 실시하였다. 한국 단일문화 및 다문화 아동 집단 각각에서 언어(수용, 표현)능력과 정서행동 특성 간 상관 관계를 확인하기 위해 피어슨 적률상관계수(Pearson's product moment correlation coefficients)를 산출하였다. 또한, 한국 단일문 
화 및 다문화 아동 집단, 그리고 불리한 언어습득 환경에 처해있음 에도 불구하고 언어능력이 정상 범주에 속하는 D-TD 집단 각각의 언어(수용, 표현) 능력을 가장 잘 설명해주는 정서행동 특성을 확인 하기 위해 단계적 다중회귀분석(Stepwise multiple regression)을 사용하였다. 본 연구의 모든 통계분석은 SPSS ver. 25 (SPSS Inc., Chicago, IL, USA)를 사용하였다.

\section{연구결과}

\section{네 집단(K-TD, K-LD, D-TD, D-LD)의 정서행동 특성의 부모-교사 보고}

강점(사회지향행동) 및 난점(과잉행동, 정서증상, 행동문제, 또래 문제)에 대하여 K-TD, K-LD, D-TD 집단에서의 부모-교사 보고의 일치 여부를 확인한 결과, 다섯 가지 정서행동 특성 모두에서 부모교사 보고 간 차이가 유의하지 않은 것으로 나타나 부모-교사의 보 고는 일관성을 보였다( $p>.05)$. 그러나, D-LD 집단에서는 난점 척도 인 정서증상 $(t=3.236, p=.006)$, 또래문제 $(t=3.643, p=.002)$ 에서 부모-교사 간 차이가 유의하였다. 즉, D-LD 집단 아동의 정서증상 에 대해 부모는 2.44 점 $(\mathrm{SD}=1.75)$ 을 부여한 반면, 교사는 .88점 $(\mathrm{SD}=1.26)$ 을 주었고, 또래문제에 대해 부모는 3.31점( $\mathrm{SD}=1.45)$ 을 부여한 반면, 교사는 1.69 점 $(\mathrm{SD}=1.08)$ 을 부여하여 부모가 교사에 비해 난점을 더 높게 인식하였다.

\section{네 집단(K-TD, K-LD, D-TD, D-LD)의 정서행동 특성의 차이}

강점(사회지향행동)에서 K-TD 집단은 7.09점( $\mathrm{SE}=.526), \mathrm{K}-\mathrm{LD}$ 집단은 5.71점(SE = .659), $\mathrm{D}-\mathrm{TD}$ 집단은 6.66점 $(\mathrm{SE}=.436), \mathrm{D}-\mathrm{LD}$ 집 단은 6.38 점 $(\mathrm{SE}=.436)$ 을 받았으며 네 집단 간 차이는 통계적으로
유의하지 않았다 $(p>.05)$.

난점에서 K-TD 집단의 평균은 2.13점( $\mathrm{SE}=.261), \mathrm{K}-\mathrm{LD}$ 집단의 평균은 3.02점( $\mathrm{SE}=.327)$, $\mathrm{D}-\mathrm{TD}$ 집단의 평균은 2.39점 $(\mathrm{SE}=.217)$, $\mathrm{D}-\mathrm{LD}$ 집단의 평균은 2.76 점 $(\mathrm{SE}=.217)$ 이었으며 네 집단 간 차이는 통계적으로 유의하지 않았다 $(p>.05)$. 난점의 세부유형(과잉행동, 정서증상, 행동문제, 또래문제)에 따른 점수는 과잉행동(Hyperactivity)의 경우 $\mathrm{K}-\mathrm{TD}$ 집단 2.91 점( $\mathrm{SE}=.518), \mathrm{K}-\mathrm{LD}$ 집단 3.29점(SE= .650), $\mathrm{D}-\mathrm{TD}$ 집단 3.56점( $\mathrm{SE}=.430), \mathrm{D}-\mathrm{LD}$ 집단 3.41점 $(\mathrm{SE}=.430)$, 정서증상(Emotional symptom)의 경우 K-TD 집단 1.77 점 $(\mathrm{SE}=.338)$, $\mathrm{K}-\mathrm{LD}$ 집단 2.79 점 $(\mathrm{SE}=.424), \mathrm{D}-\mathrm{TD}$ 집단 1.28 점 $(\mathrm{SE}=.281), \mathrm{D}-\mathrm{LD}$ 집단 1.66점( $\mathrm{SE}=.281)$, 행동문제(Conduct problem)의 경우 K-TD 집단 2.23점 $(\mathrm{SE}=.429), \mathrm{K}-\mathrm{LD}$ 집단 2.57점 $(\mathrm{SE}=.538), \mathrm{D}-\mathrm{TD}$ 집단 2.50 점( $\mathrm{SE}=.356), \mathrm{D}-\mathrm{LD}$ 집단 3.47점 $(\mathrm{SE}=.356)$, 또래문제 $(\mathrm{Peer}$ problem)의 경우 K-TD 집단 1.59 점 $(\mathrm{SE}=.423), \mathrm{K}-\mathrm{LD}$ 집단 3.43점 $(\mathrm{SE}=.530), \mathrm{D}-\mathrm{TD}$ 집단 2.22 점 $(\mathrm{SE}=.351), \mathrm{D}-\mathrm{LD}$ 집단 2.50 점 $(\mathrm{SE}=$ .351)이었다.

난점에서 네 집단의 차이는 통계적으로 유의하지 않았으나, 집단, 교사 또는 부모의 보고, 난점유형의 3 차 상호작용이 유의한 것으로 나타나 사후분석을 실시한 결과, 부모 보고 시 D-LD 집단의 난점 $(\mathrm{M}=3.25, \mathrm{SE}=.236)$ 은 $\mathrm{K}-\mathrm{TD}(\mathrm{M}=2.09, \mathrm{SE}=.284), \mathrm{D}-\mathrm{TD}(\mathrm{M}=2.20$, $\mathrm{SE}=.236)$ 집단의 난점에 비해 유의하게 높은 것으로 나타났다 $(p<.05)$. 반면, 교사 보고 시 네 집단의 난점에는 통계적으로 유의 한 차이가 없었다 $(p>.05)$. 세부 난점유형에 따른 집단 간차이를 살 펴보면, 과잉행동에서의 집단 간차이는 유의하지 않았으나( $p>.05)$, 정서증상에서의 집단 간 차이는 유의하여 D-TD 집단에 비해 K-LD 집단이 더 유의하게 많은 정서증상을 보인 것으로 나타났다 $(p=.005)$. 또한, 행동문제에서 K-TD 집단에 비해 D-LD 집단이 더 많은 행동 문제를 보인 것으로 나타났으며 $(p=.031)$, 또래문제에서 K-TD 집단

Table 3. Strength and difficulties by subgroups

\begin{tabular}{|c|c|c|c|c|c|}
\hline Variables & $\mathrm{K}-\mathrm{TD}(\mathrm{N}=11)$ & $\mathrm{K}-\mathrm{LD}(\mathrm{N}=7)$ & $\mathrm{D}-\mathrm{TD}(\mathrm{N}=16)$ & $\mathrm{D}-\mathrm{LD}(\mathrm{N}=16)$ & Post-hoc \\
\hline \multicolumn{6}{|l|}{ Strength } \\
\hline Prosocial behavior & $7.09(.526)$ & $5.71(.659)$ & $6.66(.436)$ & $6.38(.436)$ & - \\
\hline \multicolumn{6}{|l|}{ Difficulties } \\
\hline Total difficulties & $2.13(.261)$ & $3.02(.327)$ & $2.39(.217)$ & $2.76(.217)$ & - \\
\hline Hyperactivity & $2.91(.518)$ & $3.29(.650)$ & $3.56(.430)$ & $3.41(.430)$ & - \\
\hline Emotional symptom & $1.77(.338)$ & $2.79(.424)$ & $1.28(.281)$ & $1.66(.281)$ & $\mathrm{D}-\mathrm{TD}<\mathrm{K}-\mathrm{LD}^{* *}$ \\
\hline Conduct problem & $2.23(.429)$ & $2.57(.538)$ & $2.50(.356)$ & $3.47(.356)$ & $\mathrm{K}-\mathrm{TD}<\mathrm{D}-\mathrm{LD}^{*}$ \\
\hline Peer problem & $1.59(.423)$ & $3.43(.530)$ & $2.22(.351)$ & $2.50(.351)$ & $\mathrm{K}-\mathrm{TD}<\mathrm{K}-\mathrm{LD} *$ \\
\hline
\end{tabular}

Values are presented as mean (SE).

$\mathrm{K}-\mathrm{TD}=$ Korean typically developing children; $\mathrm{K}-\mathrm{LD}=$ Korean children with language delay; $\mathrm{D}-\mathrm{TD}=$ Culturally diverse typically developing children; $\mathrm{D}-\mathrm{LD}=\mathrm{Culturally}$ diverse children with language delay.

${ }^{*} p<.05,{ }^{* *} p<.01$. 

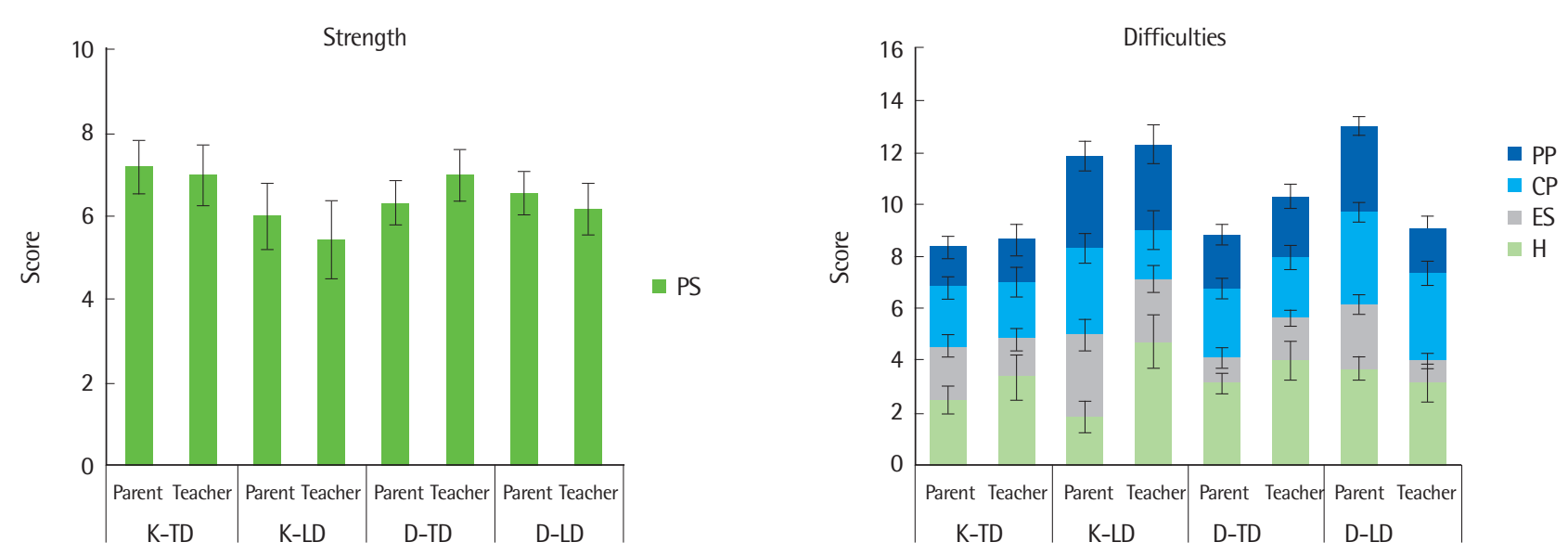

Figure 1. Emotional behavior characteristics recognized by parents-teachers in each group. $\mathrm{K}-\mathrm{TD}=$ Korean typically developing children; K-LD=Korean children with language delay; D-TD=Culturally diverse typically developing children; $\mathrm{D}-\mathrm{LD}=\mathrm{Culturally}$ diverse children with language delay; $\mathrm{PS}=$ Prosocial behavior; $\mathrm{PP}=$ Peer problem; $\mathrm{CP}=$ Conduct problem; $\mathrm{ES}=$ Emotional symptom; $\mathrm{H}=\mathrm{Hyperactivity}$.

에 비해 K-LD 집단이 더 많은 또래문제를 보인 것으로 나타났다 ( $p=.009)$. 이에 대한 결과를 Table 3, Figure 1에 제시하였다.

한국 단일문화 및 다문화 아동 집단에서의 언어(수용, 표현), 어휘(수용, 표현) 능력과 부모 및 교사가 보고한 정서행동

\section{특성 간 상관관계}

한국 단일문화 아동 집단에서의 각 변인 간 상관관계

한국 단일문화 아동 집단의 언어능력(수용, 표현), 어휘능력(수 용, 표현), 그리고 10 가지 정서행동 특성(부모가 보고한 사회지향행 동, 과잉행동, 정서증상, 행동문제, 또래문제, 교사가 보고한 사회지 향행동, 과잉행동, 정서증상, 행동문제, 또래문제) 간 관련성을 살 펴본 결과, 수용언어능력과 유의한 상관을 보인 정서행동 특성은 없었으며( $p>.05)$, 표현언어능력과 부모가 보고한 사회지향행동 $(r=.513, p=.030)$, 부모가 보고한 또래문제 $(r=-.476, p=.046)$, 그 리고 교사가 보고한 또래문제 $(r=-.553, p=.017)$ 간 유의한 상관이 나타났다. 수용 어휘능력과 유의한 상관을 보인 정서행동 특성은 없었으며( $p>.05)$, 표현 어휘능력과 교사가 보고한 또래문제 $(r=$ $-.560, p=.016)$ 간 유의한 상관이 나타났다. 한국 단일문화 일반 아 동(K-TD) 집단, 한국 단일문화 언어발달지연 아동 $(\mathrm{K}-\mathrm{LD})$ 집단으 로 세부적으로도 살펴본 결과, 언어능력(수용, 표현) 또는 어휘능력 (수용, 표현)과 유의한 상관을 보이는 정서행동 특성은 유의하지 않 았다 $(p>.05)$. 한국 단일문화 아동 집단의 세부적인 상관계수 산출 결과는 Table 4 와 같다.

\section{다문화 아동 집단에서의 각 변인 간 상관관계}

다문화 아동 집단의 언어능력(수용, 표현), 어휘능력(수용, 표현),
그리고 10 가지 정서행동 특성(부모가 보고한 사회지향행동, 과잉 행동, 정서증상, 행동문제, 또래문제, 교사가 보고한 사회지향행동, 과잉행동, 정서증상, 행동문제, 또래문제) 간 관련성을 살펴본 결과, 수용언어능력과 유의한 상관을 보인 정서행동 특성은 부모가 보고 한 과잉행동 $(r=-.386, p=.029)$ 으로 나타났으며, 표현언어능력과 유의한 상관을 보인 정서행동 특성은 없었다 $(p>.05)$. 수용 어휘능 력과 유의한 상관을 보인 정서행동 특성은 없었으나( $p>.05)$, 표현 어휘능력과 부모가 보고한 과잉행동 $(r=-.376, p=.034)$, 교사가 보 고한 사회지향행동 $(r=.395, p=.025)$ 으로 나타났다. 다문화 일반 아동(D-TD) 집단, 다문화 언어발달지연 아동(D-LD) 집단으로 세 부적으로도 살펴본 결과, D-TD 집단에서 수용언어능력과 부모가 보고한 강점(사회지향행동) 간 유의한 상관이 나타났으며 $(r=.561$, $p=.024)$, 수용 어휘능력과 부모가 보고한 사회지향행동 $(r=.572$, $p=.021)$, 표현 어휘능력과 부모가 보고한 사회지향행동 $(r=.738$, $p=.001)$, 부모가 보고한 과잉행동 $(r=-.632, p=.009)$ 으로 나타났 다. D-LD 집단에서 언어능력과 유의한 상관이 나타난 정서행동 특 성은 없었으나 $(p>.05)$. 표현 어휘능력과 교사가 보고한 사회지향 행동 $(r=.556, p=.025)$, 교사가 보고한 또래문제 $(r=-.594, p=.015)$ 간 유의한 상관이 나타났다. 다문화 아동 집단의 세부적인 상관계 수산출 결과는 Table 5 과 같다.

\section{한국 단일문화 및 다문화 아동 집단에서의 언어(수용, 표현) 능력에 대한 정서행동 특성의 예측력}

각 집단의 수용 및 표현언어능력에 대해 정서행동 특성이 유의한 예측력을 지니는지 확인한 결과, 한국 단일문화 아동 집단에서 수 용언어를 유의하게 예측해주는 정서행동 특성은 없었으나( $p>.05)$, 
Table 4. Correlation matrix in Korean mono-cultural group

\begin{tabular}{|c|c|c|c|c|c|c|c|c|c|c|}
\hline Variables & Parent PS & Parent $\mathrm{H}$ & Parent ES & Parent CP & Parent PP & Teacher PS & Teacher H & Teacher ES & Teacher CP & Teacher PP \\
\hline \multicolumn{11}{|l|}{$\mathrm{K}$} \\
\hline PRES_R & .286 & .447 & -.161 & -.209 & -.234 & .343 & -.175 & -.234 & .061 & -.451 \\
\hline PRES_E & $.513^{*}$ & .149 & -.098 & -.003 & $-.476^{*}$ & .398 & -.387 & -.389 & -.020 & $-.553^{*}$ \\
\hline REVT_R & .399 & .101 & -.078 & -.297 & -.447 & .309 & -.231 & -.162 & -.053 & -.378 \\
\hline REVT_E & .287 & -.006 & -.345 & -.154 & -.448 & .426 & -.455 & -.347 & .019 & $-.560 *$ \\
\hline \multicolumn{11}{|l|}{ K-TD } \\
\hline PRES_R & .109 & .126 & .034 & .214 & .275 & .076 & .495 & -.241 & .257 & -.169 \\
\hline PRES_E & .529 & -.236 & .377 & .373 & -.025 & .578 & -.225 & -.118 & -.022 & -.414 \\
\hline REVT_R & .251 & -.597 & .106 & .114 & -.412 & .282 & .395 & -.213 & .064 & -.117 \\
\hline REVT_E & .231 & -.505 & -.070 & -.145 & -.193 & .374 & -.161 & -.150 & .156 & -.303 \\
\hline \multicolumn{11}{|l|}{ K-LD } \\
\hline PRES_R & .269 & .611 & -.034 & -.211 & -.062 & .401 & -.616 & .001 & -.623 & -.405 \\
\hline PRES_E & .420 & .212 & -.124 & .156 & -.369 & .056 & -.408 & -.300 & -.304 & -.468 \\
\hline REVT_R & .394 & .303 & .145 & -.258 & -.077 & .113 & -.517 & .137 & -.643 & -.246 \\
\hline REVT_E & .162 & .282 & -.450 & .101 & -.357 & .312 & -.717 & -.303 & -.671 & -.632 \\
\hline
\end{tabular}

$\mathrm{PS}=$ Prosocial behavior; $\mathrm{H}=$ Hyperactivity; $\mathrm{ES}=$ Emotional symptom; $\mathrm{CP}=$ Conduct problem; PP=Peer problem; PRES_R=Receptive language; PRES_E=Expressive language;

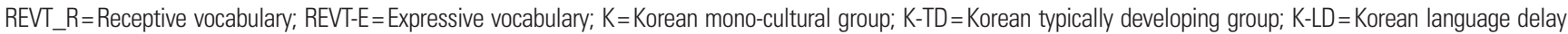
group; PRES = Preschool Receptive \& Expressive Language Scale (Kim, Sung, \& Lee, 2003); REVT=Receptive and Expressive Vocabulary Test (Kim, Hong, Kim, Jang, \& Lee, 2009).

${ }^{*} p<.05$.

Table 5. Correlation matrix in culturally diverse group

\begin{tabular}{|c|c|c|c|c|c|c|c|c|c|c|}
\hline Variables & Parent PS & Parent H & Parent ES & Parent CP & Parent PP & Teacher PS & Teacher H & Teacher ES & Teacher CP & Teacher PP \\
\hline \multicolumn{11}{|l|}{$\bar{D}$} \\
\hline PRES_R & .321 & $-.386^{*}$ & -.037 & .104 & -.211 & .155 & -.024 & -.074 & .081 & .067 \\
\hline PRES_E & -.002 & -.139 & -.110 & .131 & -.099 & .195 & .037 & .086 & -.024 & .066 \\
\hline REVT_R & .170 & -.266 & -.020 & -.024 & -.095 & .310 & .080 & .172 & -.170 & .014 \\
\hline REVT_E & .218 & $-.376^{*}$ & -.181 & -.144 & -.300 & $.395^{*}$ & -.071 & .055 & -.040 & -.027 \\
\hline \multicolumn{11}{|l|}{ D-TD } \\
\hline PRES_R & $.561^{*}$ & -.327 & .091 & .367 & -.114 & .027 & .051 & -.415 & .228 & .074 \\
\hline PRES_E & .138 & .148 & .127 & .485 & .259 & -.048 & .196 & -.163 & .153 & .096 \\
\hline REVT_R & $.572^{*}$ & -.333 & .430 & .309 & .071 & .329 & .207 & -.225 & .080 & .052 \\
\hline REVT_E & $.738^{* *}$ & $-.632^{* *}$ & .089 & .140 & -.259 & .130 & -.039 & -.399 & .075 & .181 \\
\hline \multicolumn{11}{|l|}{ D-LD } \\
\hline PRES_R & .147 & -.419 & .125 & .020 & -.122 & .259 & -.234 & .208 & .058 & -.145 \\
\hline PRES_E & -.011 & -.210 & .229 & .313 & .117 & .261 & -.229 & -.038 & .165 & -.262 \\
\hline REVT_R & .053 & -.142 & .267 & .089 & .237 & .213 & -.164 & .218 & -.132 & -.400 \\
\hline REVT_E & .203 & -.298 & .136 & .007 & -.030 & $.556^{*}$ & -.291 & -.052 & .207 & $-.594^{*}$ \\
\hline
\end{tabular}

$\mathrm{PS}=$ Prosocial behavior; $\mathrm{H}=$ Hyperactivity; $\mathrm{ES}=$ Emotional symptom; $\mathrm{CP}=$ Conduct problem; PP=Peer problem; PRES_R=Receptive language; PRES_E=Expressive language;

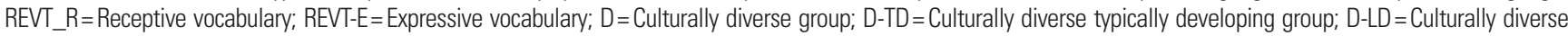
language delay group; PRES = Preschool Receptive \& Expressive Language Scale (Kim, Sung, \& Lee, 2003); REVT = Receptive and Expressive Vocabulary Test (Kim, Hong, Kim, Jang, \& Lee, 2009).

${ }^{*} p<.05,{ }^{* *} p<.01$.

표현언어에 대해 교사의 또래문제 보고 $\left(r^{2}=.306, p=.017\right)$ 가 유의 한 예측력을 보였다. 한국 단일문화 아동 집단 내에서도 일반 아동 (K-TD) 및 언어발달지연 아동 $(\mathrm{K}-\mathrm{LD})$ 각각의 언어능력에 대한 정서 행동 특성의 예측력을 알아본 결과, 통계적으로 유의한 예측요인
은 없었다 $(p>.05)$

다문화 아동 집단에서 수용언어를 유의하게 예측해주는 정서행 동 특성은 부모의 과잉행동 보고 $\left(r^{2}=.149, p=.029\right)$ 였으며, 표현언 어를 유의하게 예측해주는 정서행동 특성은 없었다 $(p>.05)$. 다문 
Table 6. Regression table

\begin{tabular}{lcccc}
\hline \multirow{2}{*}{ Node } & $\mathrm{K}(\mathrm{N}=18)$ & & $\mathrm{D}(\mathrm{N}=32)$ & $\mathrm{D}-\mathrm{TD}(\mathrm{N}=16)$ \\
\cline { 2 - 2 } \cline { 5 - 5 } & $\begin{array}{c}\text { Dependent variable: } \\
\text { Expressive language }\end{array}$ & & $\begin{array}{c}\text { Dependent variable: } \\
\text { Receptive language }\end{array}$ \\
\hline Teacher_PP $(\beta)$ & $-.553^{*}$ & & & \\
Parent_H $(\beta)$ & & & $-.386^{*}$ & \\
Parent_PS $(\beta)$ & $.306^{*}$ & & $.149^{*}$ & $.311^{*}$ \\
$R^{2}$ & $7.044^{*}$ & & $5.249^{*}$ & $6.442^{*}$ \\
$F$ & & & &
\end{tabular}

$\mathrm{K}=$ Korean mono-cultural group; $\mathrm{D}=$ Culturally diverse group; $\mathrm{D}-\mathrm{TD}=$ Culturally diverse typically developing group; $\mathrm{PP}=$ Peer problem; $\mathrm{H}=$ Hyperactivity; PS = Prosocial behavior.

${ }^{*} p<.05$.

화 아동 집단 내에서도 일반 아동(D-TD) 및 언어발달지연 아동 (D-LD) 각각의 언어능력에 대한 정서행동 특성의 예측력을 알아 본 결과, D-TD 집단에서 수용언어에 대해 부모의 강점(사회지향행 동) 보고 $\left(r^{2}=.315, p=.024\right)$ 가 유의한 예측력을 보였으며, D-LD 집 단에서는 언어능력에 대해 정서행동 특성이 유의한 예측력을 나타 내지 않았다( $p>.05)$. 이에 대한 내용을 Table 6에 제시하였다.

\section{논의 및 결론}

본 연구에서는 다문화 및 또래 한국 단일문화 아동의 정서행동 특성에 대한 부모와 교사의 보고가 일치하는지, 다문화 및 또래 한 국 단일문화 아동 집단의 정서행동 특성은 집단 간 차이가 나타나 는지, 다문화 및 또래 한국 단일문화 아동 집단의 정서행동 특성은 언어능력과 유의한 상관을 보이는지, 다문화 및 단일문화 아동 집 단에서 부모와 교사의 보고 중 어떤 정서행동 특성이 언어능력을 잘 설명하는지, 궁극적으로는 다문화 일반 아동(D-TD) 집단의 평 균 범주에 속하는 언어능력을 설명해주는 보호요인으로 정서행동 특성 중 강점(사회지향행동)이 언어능력을 유의하게 설명해줄 수 있는지 확인해보고자 하였다. 그 결과에 대한 논의는 다음과 같다.

첫째, 네 집단 모두 강점(사회지향행동)에서는 부모-교사 보고의 유의한 차이가 나타나지 않았으나, 난점의 경우 다문화 언어발달지 연 아동(D-LD) 집단에 한하여 부모가 교사보다 자녀의 정서증상, 또래문제가 유의하게 더 많다고 보고하였다. D-LD 집단을 제외한 K-TD, K-LD, D-TD 집단에서 강점 및 난점을 통틀어 부모 및 교사 보고의 일관성이 나타난 것은, 학령전기의 어린 아동과 가장 가까 운 보호자 및 교사의 보고가 상당히 높은 신뢰도를 보일 수 있음을 의미한다(Becker, Hasselhorn, Banaschewski, \& Rothenberger, 2004). 즉, 자녀에 대해 부모 또는 교사가 제공한 정보가 다소주관적 일 수는 있으나 부모 또는 교사 보고의 일치가 중요한 임상적 정보
를 제공해주므로 부모와 교사 보고를 함께 받는 것의 중요성이 강조 된다(Minke, Sheridan, Kim, Ryoo, \& Koziol, 2014; Mitsis, McKAY, Schulz, Newcorn, \& Halperin, 2000). 한편, D-LD 집단의 경우에는 다문화 가정의 부모가 교사보다 전반적으로 자녀에 대해 부정적으 로 평가했던 선행연구와 일부 일치되는 결과라 볼 수 있다(Lee \& Choi, 2012). 이러한 결과는 다문화 가정의 부모 중 한 명이 한국 문 화에 대한 이해가 부족하거나, 설문 내용을 명확하게 이해하지 못했 을 경우 교사의 보고와 일치하지 않는 결과에 기여했을 수 있다.

둘째, 네 집단의 정서행동 특성의 차이는 강점에서는 나타나지 않았으나, 난점에서는 부모 보고에서 D-LD 집단이 K-TD, D-TD 집 단에 비해 더 많은 것으로 나타나 차이를 보였다. 세부적으로는, 정 서증상은 K-LD 집단이 D-TD 집단에 비해 유의하게 더 많았고, 행 동문제는 D-LD 집단이 K-TD 집단에 비해 유의하게 더 많았으며, 또래문제는 K-LD 집단이 K-TD 집단에 비해 유의하게 더 많았다. 이는 대다수의 아동들이 언어발달지연 유무와는 상관없이 정상 범주 내의 사회지향행동을 보였던 것과는 달리 난점(특히, 또래문 제)에서는 $\mathrm{TD}$ 및 $\mathrm{LD}$ 집단 간 차이를 보였던 선행연구와 일치하며, 언어발달지연이 있을수록 더 부족한 사회적 행동을 보일 수 있음을 확인하였다(Conti-Ramsden et al., 2013; Durkin \& Conti-Ramsden, 2007; Hart et al., 2004; St Clair et al., 2011). 특히, 난점의 세부 척도인 정서행동 특성에서 K-LD 집단이 D-TD 집단보다도 유의하 게 많게 나타난 것을 볼 때, 다문화 가정 아동들이 평균 범주의 언 어능력을 갖추었을 때 내면화 및 외현화 문제에서 또래 한국 단일 문화 아동과 비교했을 때 유의한 문제를 보이지 않을 수 있음을 확 인해볼 수 있다(Kim \& Hong, 2017). 반면, K-LD, D-LD 아동과 같 이 현재 가진 의사소통능력으로는 의사표현의 한계를 보일 가능성 이 높은 경우 문화적 배경에 관계없이 내재화 문제(정서증상), 외현 화 문제(행동문제, 또래문제)가 두드러지게 나타날 수 있다.

셋째, 한국 단일문화 아동 집단의 경우 표현언어능력과 부모가 보고한 사회지향행동, 또래문제와 유의한 상관이 있었으며, 교사가 보고한 또래문제와도 유의한 상관이 나타났다. 이는 아동들의 정 서행동 특성이 지속적으로 언어와 관련되어 있음을 보고한 선행연 구와 일치한다(O'Kearney \& Goh, 2012; Valiente et al., 2011). 즉, 긍 정적 정서행동 특성인 사회지향행동이 아동들의 언어능력과 정적 으로 관련될 수 있으며, 부정적 정서행동 특성인 또래문제는 언어 능력과 부적인 상관관계를 지닐 수 있다(Bagwell et al., 1998; Campbell et al., 2000; Durkin \& Conti-Ramsden, 2007; Lonigan et al., 1999; St Clair et al., 2011). 특히, 또래문제의 경우, 부모와 교사가 보 고한 또래문제 모두 표현언어와 유의한 상관이 나타나 또래문제가 언어습득에 방해되는 요소가 될 수 있음을 추론해볼 수 있다(Con- 
ti-Ramsden et al., 2013; O’Kearney \& Goh, 2012; Valiente et al., 2011). 반면, 다문화 아동 집단의 경우 수용언어능력과 부모가 보고 한 과잉행동과 유의한 상관이 있었으며, 다문화 아동 집단 내에서 도 언어능력이 정상 범주에 속하는 D-TD 집단은 수용언어능력과 부모가 보고한 사회지향행동과 유의한 상관이 나타났다. 주목할 점은, $\mathrm{D}-\mathrm{TD}$ 집단은 전반적으로 교사의 보고보다도 일관적으로 부 모가 보고한 정서행동 특성이 언어능력과 유의한 상관을 보였다는 것이다. 이는 부모 보고의 중요성이 이미 수많은 선행연구들을 통 해 입증되어 왔으나, 특히 다문화 일반 아동의 경우 그 중요성이 더 욱 강조될 수 있음을 시사한다(Achenbach et al, 2008). 어휘의 측면 에서는 다문화 아동 집단의 표현 어휘와 교사가 보고한 사회지향 행동이 상당히 높은 관련이 있었고, 특히 다문화 아동 중 언어발달 지연이 있는 D-LD 집단에서는 표현 어휘와 교사가 보고한 사회지 향행동, 또래문제가 유의한 상관이 나타났다. 이는 한국 단일문화 아동 집단과 유사하게 긍정적 정서행동 특성인 사회지향행동, 부정 적 정서행동 특성인 또래문제가 언어(어휘)와 관련될 수 있음을 보 여준다(Bagwell et al., 1998; Campbell et al., 2000; Durkin \& Conti-Ramsden, 2007; Lonigan et al., 1999; St Clair et al., 2011).

넷째, 한국 단일문화 아동 집단의 표현언어능력을 가장 잘 설명 해주는 정서행동 특성은 교사가 보고한 또래문제 였으며, 다문화 아동 집단의 수용언어능력을 가장 잘 설명해주는 정서행동 특성은 부모가 보고한 과잉행동 이었다. 또래관계의 형성은 가족구성원 또는 교사와의 관계와는 대조적으로 주로 어린이집이나 유치원과 같은 사회적 집단에 속하게 되면서 상호성과 동등성을 기초로 자발 적으로 맺어지는 관계이며, 친밀한 또래관계는 의사소통의 경험을 풍부하게 만들며 언어능력에도 유의한 기여를 할 수 있다(ContiRamsden et al., 2013). 친밀한 또래관계를 형성한 아동들은 사회적 집단에서의 생활이 즐겁다고 느끼고, 이것이 활발한 사회적 상호 작용을 가능하게 하므로 언어능력에도 유의한 설명력을 보인 것으 로 추론해볼 수 있다(Coolahan et al., 2000). 다문화 아동의 부모가 보고한 난점(과잉행동)은 타인과 관계 맺기를 어렵게 만들어 언어 결함과도 밀접하게 연결될 수 있는 것으로 보인다(Adams et al., 1999). 과잉행동은 언어습득을 방해할 수 있다고 보고되는데(Hughes \& Ensor, 2008; Speltz et al., 1999), 실제로 환경적인 측면에서 의사소 통에 어려움을 경험하기 쉬운 다문화 아동은 타인과 관계 맺기, 자 신의 요구와감정을 표현하기, 타인의 말을 이해하기 등의 어려움이 좌절과 고통을 유발할 수 있으므로 충동성, 주의집중의 부족, 공격 성 등을 나타내기 쉬우며 이것이 언어능력에 유의한 설명력을 보인 것으로 분석된다(Brinton \& Fujiki, 1993; Brinton \& Fujiki, 2010; Fujiki et al., 2002; Ketelaars et al., 2010; Lindsay et al., 2007; Tomb- lin et al., 2000). 한편, 다문화 아동 집단 내에서도 언어능력이 정상 범주에 드는 D-TD 아동 집단에서는 부모의 강점(사회지향행동) 척도가 언어능력을 가장 유의하게 설명하는 것을 확인하였다. 이 는 앞서 살펴본 D-LD 집단의 경우 부모들이 어린이집 교사에 비해 자녀의 난점을 유의하게 더 많은 것으로 인식한 반면, D-TD 집단의 부모들은 강점과 난점에서 모두 어린이집 교사와 일관된 보고가 있 었을 뿐 아니라 한국 단일문화 아동 집단과 비교하여도 정서행동 문제가 많지 않은 특성을 보여주었고, 이들의 언어능력에 대해 난점 이 아닌 강점(사회지향행동)이 유의한 예측요인임을 확인하였다. 즉, 이들의 언어능력에 부정적 특성이 아닌 긍정적 특성이 가장 높 은 설명력을 지닌다는 것이다. 선행연구에서 사회적 정서행동의 증 진이 읽기쓰기에 긍정적 영향을 주었던 것은 경제적으로 어려운 이 민자 출신의 학생 중에서도 사회의 언어인 영어 사용능력이 부족 하지 않았던 학생들에 나타난 결과를 토대로 볼 때, 다문화 아동임 에도 불구하고 언어발달이 정상 범주에 속하는 D-TD 집단에서 정 서행동 특성 상의 강점이 언어능력에 유용하게 활용될 수 있었음 을 추론해볼 수 있다(Sung, 2014). 그리고 D-TD 집단에서 교사-부 모 간 일관된 보고가 있었음에도 불구하고 교사의 척도가 아닌 부 모의 보고가 언어능력을 유의하게 설명해주는 것 또한 주목할 점 이다. 즉, 아동의 언어능력에 부모가 인지하는 아동의 정서행동 특 성이 매우 중요한 요인일 수 있다. 특히, D-TD 집단의 경우 정서행 동 특성의 강점이 언어능력에 미치는 긍정적인 영향을 생각해볼 때, 아동의 친 사회적 정서행동 특성의 발현이 언어능력에 유의한 기여를 할 수 있음을 확인할수 있다.

본 연구의 제한점은 첫째, D-LD 집단에서 부모-교사 간 정서행 동 특성 보고의 불일치가 어린이집 담임교사의 다문화 아동에 대 한 경험의 부족으로 인한 것인지, 또는 부모의 한국 문화에 대한 이 해 부족으로 인한 것인지 확인하기 위해서는 교사의 다문화 아동 지도경력, 또는 부모의 한국 문화 이해 양상 등을 확인해야 하지만 이에 대해 확인하지 못하였다. 둘째, 다문화아동 집단의 수 $(\mathrm{N}=32)$ 에 비해 한국 단일문화 아동 집단의 수 $(\mathrm{N}=18, \mathrm{TD}=11, \mathrm{LD}=7)$ 가 현저히 적으므로 한국 단일문화 아동의 언어능력을 설명하는 정서 행동 특성이 유의한 예측요인으로 나타나지 않았을 가능성이 있 다. 한국 단일문화 아동의 수가 보다 많이 확보된다면 이들의 언어 능력을 예측하는 정서행동 특성의 유의성을 보다 명확하게 검증할 수 있을 것으로 보인다.

\section{REFERENCES}

Adams, J. W., Snowling, M. J., Hennessy, S. M., \& Kind, P. (1999). Problems 
of behaviour, reading and arithmetic: assessments of comorbidity using the Strengths and Difficulties Questionnaire. British Journal of Educational Psychology, 69(4), 571-585.

Ahn, J. S., Jun, S. K., Han, J. K., Noh, K. S., \& Goodman, R. (2003). The development of a Korean version of the Strengths and Difficulties Questionnaire. Journal of Korean Neuropsychiatric Assocication, 42(1), 141-147.

Atzaba-Poria, N., Pike, A., \& Deater-Deckard, K. (2004). Do risk factors for problem behaviour act in a cumulative manner? an examination of ethnic minority and majority children through an ecological perspective. Journal of Child Psychology and Psychiatry, 45(4), 707-718.

Achenbach, T. M., Becker, A., Döpfner, M., Heiervang, E., Roessner, V., Steinhausen, H. C., \& Rothenberger, A. (2008). Multicultural assessment of child and adolescent psychopathology with ASEBA and SDQ instruments: research findings, applications, and future directions. Journal of Child Psychology and Psychiatry, 49(3), 251-275.

Bagwell, C. L., Newcomb, A. F., \& Bukowski, W. M. (1998). Preadolescent friendship and peer rejection as predictors of adult adjustment. Child Development, 69(1), 140-153.

Becker, A. W., Hasselhorn, W., \& Banaschewski, M. T., \& Rothenberger, A. (2004). Validation of the parent and teacher SDQ in a clinical sample. $E u$ ropean Child and Adolescent Psychiatry, 13(2), 11-16.

Bishop, D. V., \& McDonald, D. (2009). Identifying language impairment in children: combining language test scores with parental report. International Journal of Language \& Communication Disorders, 44(5), 600-615.

Brinton, B., \& Fujiki, M. (1993). Language, social skills, and socioemotional behavior. Language, Speech, and Hearing Services in Schools, 24(4), 194198.

Brinton, B., \& Fujiki, M. (2010). “The social stuff is everything”: How social differences in development impact treatment for children with language impairment. In A. L. Weiss (Ed.), Perspectives on individual differences affecting therapeutic change in communication disorders. New directions in communications disorders research (pp. 7-27). New York, NY US: Psychology Press.

Bulotsky-Shearer, R. J., Dominguez, X., \& Bell, E. R. (2012). Preschool classroom behavioral context and school readiness outcomes for low-income children: a multilevel examination of child-and classroom-level influences. Journal of Educational Psychology, 104(2), 421-438

Byun, S. Y., \& Son, K. W. (2011). A case study of children from multicultural family and it' implication to multicultural virtue research -focused on the social and emotional competency in children from multicultural family.
Journal of Ethics Education Studies, 26, 137-166.

Campbell, S. B., Shaw, D. S., \& Gilliom, M. (2000). Early externalizing behavior problems: toddlers and preschoolers at risk for later maladjustment. Development and Psychopathology, 12(3), 467-488.

Choi, Y. J., Kim, Y. S., Sun, B. Y., Cheong, H. S., Yang, K., Lee, E. A., \& Hwang, J. M. (2019). 2018 National Multicultural Family Survey. Korean Women's development institute.

Conti-Ramsden, G., Mok, P. L., Pickles, A., \& Durkin, K. (2013). Adolescents with a history of specific language impairment (SLI): strengths and difficulties in social, emotional and behavioral functioning. Research in Developmental Disabilities, 34(11), 4161-4169.

Coolahan, K., Fantuzzo, J., Mendez, J., \& McDermott, P. (2000). Preschool peer interactions and readiness to learn: Relationships between classroom peer play and learning behaviors and conduct. Journal of Educational Psychology, 92(3), 458-465.

Durkin, K., \& Conti-Ramsden, G. (2007). Language, social behavior, and the quality of friendships in adolescents with and without a history of specific language impairment. Child Development, 78(5), 1441-1457.

Fujiki, M., Brinton, B., \& Clarke, D. (2002). Emotion regulation in children with specific language impairment. Language, Speech, and Hearing Services in Schools, 33(2), 102-111.

Goodman, R. (1997). The strengths and difficulties questionnaire: a research note. Child Psychology \& Psychiatry \& Allied Disciplines, 38(5), 581-586.

Goodman, R., \& Scott, S. (1999). Comparing the strengths and difficulties questionnaire and the child behavior checklist: is small beautiful?. Journal of Abnormal Child Psychology, 27(1), 17-24.

Han, J., \& Yim, D. (2018). Korean brief parent report measures of language development in children with vocabulary delay. Journal of Speech-Language \& Hearing Disorders, 27(2), 69-84.

Hart, K. I., Fujiki, M., Brinton, B., \& Hart, C. H. (2004). The relationship between social behavior and severity of language impairment. Journal of Speech, Language, and Hearing Research, 47(3), 647-662.

Hartup, W. W. (1992). Peer relations in early and middle childhood. In V. B. Van Hasselt \& M. Hersen (Eds.), Handbook of social development: a lifespan perspective (pp. 257-281). New York: Plenum Press

Hughes, C., \& Ensor, R. (2008). Does executive function matter for preschoolers' problem behaviors?. Journal of abnormal child psychology, 36(1), 1-14.

Im, E. J., \& Jeong, M. J. (2010). Variables related to behavior problems of children with communication disorders. Korean Journal of Communication \& Disorders, 15(1), 79-93. 
Ketelaars, M. P., Cuperus, J., Jansonius, K., \& Verhoeven, L. (2010). Pragmatic language impairment and associated behavioural problems. International Journal of Language \& Communication Disorders, 45(2), 204-214.

Kim, H. K., Ahn, J. S., \& Kim, M. H. (2012). Agreement between parent and teacher reports in clinical setting: comparing SDQ-Kr with K-CBCL. Journal of the Korean Academy of Child and Adolescent Psychiatry, 23(3), 127133.

Kim, S. J., \& Hong, C. H. (2017). The effect of discrimination experience and language problems on psychosocial adjustment in children with multi-cultural family: the moderating effect of ego-resilience and family strengths. Korea Journal of Youth Studies, 24(1), 195-211.

Kim, Y. T., Hong, G. H., Kim, K. H., Jang, H. S., \& Lee, J. Y. (2009). Receptive \& expressive vocabulary test (REVT). Seoul: Seoul Community Rehabilitation Center.

Kim, Y. T., Sung, T. J., \& Lee, Y. K. (2003). Preschool Receptive-Expressive Language Scale (PRES). Seoul: Seoul Welfare Center for People with Disabilities.

Lee, S. Y., \& Choi, J. A. (2012). A comparison study of parent and teacher ratings on protective factors and behavioral concerns of young children from multicultural families. Journal of Educational Studies, 43(3), 59-84.

Lee, E. J., \& Oh, S. J. (2019). Association between pragmatic language competence and emotional/behavioral outcomes of 3rd graders in elementary school. Communication Sciences \& Disorders, 24(4), 906-924.

Lindsay, G., Dockrell, J. E., \& Strand, S. (2007). Longitudinal patterns of behaviour problems in children with specific speech and language difficulties: child and contextual factors. British Journal of Educational Psychology, 77(4), 811-828.

Lonigan, C. J., Bloomfield, B. G., Anthony, J. L., Bacon, K. D., Phillips, B. M., \& Samwel, C. S. (1999). Relations among emergent literacy skills, behavior problems, and social competence in preschool children from low-and middle-income backgrounds. Topics in Early Childhood Special Education, 19(1), 40-53.

Minke, K. M., Sheridan, S. M., Kim, E. M., Ryoo, J. H., \& Koziol, N. A. (2014). Congruence in parent-teacher relationships: the role of shared perceptions. The Elementary School Journal, 114(4), 527-546.

Mitsis, E. M., McKAY, K. E., Schulz, K. P., Newcorn, J. H., \& Halperin, J. M. (2000). Parent-teacher concordance for DSM-IV attention-deficit/hyperactivity disorder in a clinic-referred sample. Journal of the American Academy of Child \& Adolescent Psychiatry, 39(3), 308-313.
Montroy, J. J., Bowles, R. P., Skibbe, L. E., \& Foster, T. D. (2014). Social skills and problem behaviors as mediators of the relationship between behavioral self-regulation and academic achievement. Early Childhood Research Quarterly, 29(3), 298-309.

Moon, S. B., \& Byun, C. J. (2003). Korean Kaufman assessment battery for children (K-ABC). Seoul: Hakjisa.

O'Kearney, R., \& Goh, S. (2012). Emotional and behavioural outcome for children with early communication difficulties: evidence from the longitudinal study of Australian children (LSAC). Neuropsychiatrie de l'Enfance et de l'Adolescence, 60(5), S166.

Rose-Krasnor, L. (1997). The nature of social competence: a theoretical review. Social Development, 6(1), 111-135.

Speltz, M. L., DeKlyen, M., Calderon, R., Greenberg, M. T., \& Fisher, P. A. (1999). Neuropsychological characteristics and test behaviors of boys with early onset conduct problems. Journal of Abnormal Psychology, 108(2), 315-325.

St Clair, M. C., Pickles, A., Durkin, K., \& Conti-Ramsden, G. (2011). A longitudinal study of behavioral, emotional and social difficulties in individuals with a history of specific language impairment (SLI). Journal of Communication Disorders, 44(2), 186-199.

Sung, Y. (2014). Differential effect of social-emotional behaviors on academic achievement of language-minority students. Child \& Youth Care Forum, 43(3), 393-416.

Thijs, J., \& Verkuyten, M. (2017). Promoting positive self-esteem in ethnic minority children: the role of school and classroom context. In N. J. Carbera \& B. Leyendecker (Eds.), Handbook on Positive Development of Minority Children and Youth (pp. 325-342). Cham: Springer.

Tomblin, J. B., Zhang, X., Buckwalter, P., \& Catts, H. (2000). The association of reading disability, behavioral disorders, and language impairment among second-grade children. The Journal of Child Psychology and Psychiatry and Allied Disciplines, 41(4), 473-482.

Valiente, C., Eisenberg, N., Haugen, R. G., Spinrad, T. L., Hofer, C., Liew, J., \& Kupfer, A. (2011). Children's effortful control and academic achievement: Mediation through social functioning. Early Education \& Development, 22(3), 411-433.

Zadeh, Z. Y., Im-Bolter, N., \& Cohen, N. J. (2007). Social cognition and externalizing psychopathology: an investigation of the mediating role of language. Journal of Abnormal Child Psychology, 35(2), 141-152. 
Appendix 1. The strengths and difficulties questionnaire (SDQ-Kr, Ahn et al., 2003)

\begin{tabular}{|l|l|l|l|}
\hline Coding No. & 평가일 (YY.MM.DD) & \\
\hline 아동이름 (성별) & 생년월일 (C.A) & \\
\hline 정보제공자 이름 & 아동과의 관계 & 부 / 모/ 기타( \\
\hline
\end{tabular}

\begin{tabular}{|c|c|c|c|c|c|c|}
\hline 구분 & \multicolumn{2}{|c|}{ 하위분류 } & 내용 & $\begin{array}{c}\text { 전혀 } \\
\text { 아니다 }\end{array}$ & $\begin{array}{c}\text { 다소 } \\
\text { 그렇다 }\end{array}$ & $\begin{array}{l}\text { 분명히 } \\
\text { 그렇다 }\end{array}$ \\
\hline 1 & 강점 & 사회지향행동 & 다른 사람의 감정을 배려한다. & & & \\
\hline 2 & 난점 & 과잉행동 & 차분하지 않고, 부산하며, 오랫동안 가만히 있지 못한다. & & & \\
\hline 3 & 난점 & 정서증상 & 자주 두통이나 복통을 호소하거나 몸이 아프다고 한다. & & & \\
\hline 4 & 강점 & 사회지향행동 & 간식, 장난감, 또는 연필 등을 기꺼이 다른 아이들과 함께 나눈다. & & & \\
\hline 5 & 난점 & 행동문제 & 자주 분노발작을 보이거나, 불같이 성질을 부린다. & & & \\
\hline 6 & 난점 & 또래문제 & 주로 홀로 있고, 혼자서 노는 편이다. & & & \\
\hline 7 & 난점 & 행동문제(역) & 일반적으로 순종적이고, 평소에 어른이 시키는 대로 한다. & & & \\
\hline 8 & 난점 & 정서증상 & 걱정이 많고, 종종 근심스러워 보인다. & & & \\
\hline 9 & 강점 & 사회지향행동 & 누군가가 다치거나, 몸 상태가 나쁘거나, 아파 보이면 도움을 준다. & & & \\
\hline 10 & 난점 & 과잉행동 & 언제나 안절부절 못하고 꼼지락거린다. & & & \\
\hline 11 & 난점 & 또래문제(역) & 적어도 한 명 이상의 절친한 친구가 있다. & & & \\
\hline 12 & 난점 & 행동문제 & 다른 아이들에게 종종 싸움을 걸거나, 괴롭힌다. (때리기, 위협하기, 빼앗기). & & & \\
\hline 13 & 난점 & 정서증상 & 자주 불행해 보이고, 낙담하며, 눈물이 고인다. & & & \\
\hline 14 & 난점 & 또래문제(역) & 대체로 다른 아이들이 내 자녀를 좋아한다. & & & \\
\hline 15 & 난점 & 과잉행동 & 쉽게 주의가 분산되고 집중력이 산만하다. & & & \\
\hline 16 & 난점 & 정서증상 & 낯선 상황에서는 불안해지거나 안 떨어지려 하고, 쉽사리 자신감을 잃는다. & & & \\
\hline 17 & 강점 & 사회지향행동 & 자신보다 어린 아등들에게 친절하다. & & & \\
\hline 18 & 난점 & 행동문제 & 종종 거짓말을 하거나 속인다. & & & \\
\hline 19 & 난점 & 또래문제 & 다른 아이들에게 놀림을 받거나 괴롭힘을 당한다. & & & \\
\hline 20 & 강점 & 사회지향행동 & 자주 부모나 선생님, 또는 다른 아이들을 자진해서 돕는다. & & & \\
\hline 21 & 난점 & 과잉행동(역) & 곰곰이 생각한 다음에 행동한다. & & & \\
\hline 22 & 난점 & 행동문제 & 가정이나 학교 또는 어떤 곳에서 훔친다. & & & \\
\hline 23 & 난점 & 또래문제 & 또래 아이들보다 어른들과 더 잘 지낸다. & & & \\
\hline 24 & 난점 & 정서증상 & 두려움이 많고 무서움을 잘 탄다. & & & \\
\hline 25 & 난점 & 과잉행동(역) & 주어진 일을 끝까지 마치고, 주의력을 잘 유지한다. & & & \\
\hline
\end{tabular}




\section{국문초록}

\section{한국 단일문화 및 다문화 아동의 정서행동 특성에 대한 부모 및 교사의 보고와 언어능력의 관계 양윤희 · 임동선 \\ 이화여자대학교 언어병리학과}

배경 및 목적: 본 연구에서는 다문화 및 또래 일반아동의 정서행동 특성에 대한 부모와 교사의 보고가 일치하는지, 다문화 및 단일문 화 아동 집단에서 부모와 교사의 보고 중 어떤 정서행동 특성이 언어능력을 잘 설명하는지, 궁극적으로는 다문화 일반 아동 집단의 잔 존하는 언어능력을 설명해주는 보호요인으로 정서행동 특성 중 강점(사회지향행동)이 언어능력을 유의하게 설명하는지 확인해보고 자 하였다. 방법: 본 연구의 참여아동은 만 4-6세의 한국 단일문화 아동 18 명과 다문화 아동 32 명, 총 50 명의 아동과 그들의 부모, 교사 를 대상으로 하였다. 정서행동 특성은 한국어판 강점 난점 설문지를 사용하여 강점인 사회지향행동, 난점인 과잉행동, 정서증상, 행동 문제, 또래문제를 측정하였다. 결과: 다문화 언어발달지연 아동의 경우 교사보다 부모가 아동의 난점을 더 높게 인식한 것을 제외하고, 각 집단 아동의 정서행동 특성에 대한 부모-교사의 보고는 일치하였다. 한국 단일문화 아동 집단은 교사의 또래문제 보고가 표현언어 를 유의하게 설명해준 반면, 다문화 아동 집단은 부모의 과잉행동 보고가 수용언어를 유의하게 설명하여 차이를 보였다. 다문화 일반 아동 집단의 경우 부모의 사회지향행동 보고가 수용언어를 유의하게 설명하였다. 논의 및 결론: 다문화 아동 집단은 부모의 보고가수 용언어능력을 유의하게 설명하여 다문화 아동 집단에게서 부모보고의 중요성이 더욱 강조된다. 특히, 다문화 아동 중 정상적 언어발달 을 경험하는 집단의 경우 부모가 보고한 아동의 사회지향행동의 발현이 언어능력에 유의한 기여할 수 있음을 확인하였다.

핵심어: 다문화 아동, 부모-교사 보고, 강점 난점 설문지, 사회지향행동, 언어능력

본 논문은 2018년 대한민국 교육부와한국연구재단의 지원을 받아수행된 연구임(No. NRF-2018S1A3A2075274).

\section{참고문헌}

김수진, 홍창희(2017). 다문화가정 자녀의 차별경험과 언어문제가 심리사회적 적응에 미치는 영향: 자아탄력성과 가족건강성의 조절효과. 청소년학 연구, 24(1), 195-211.

김영태, 성태제, 이윤경(2003). 취학 전 아동의 수용언어 및 표현언어 발달척도 (Preschool Receptive-Expressive Language Scale; PRES). 서울: 서울 장애인복지관.

김영태, 홍경훈, 김경희, 장혜성, 이주연(2009). 수용·표현어휘력검사(Receptive \& expressive vocabulary test; REVT). 서울: 서울장애인종합복지관. 김흥규, 안정숙, 김민혁(2012). 임상에서 부모-교사 보고의 일치:SDQ-Kr과 K-CBCL의 비교. 소아청소년정신의학, 23(3), 127-133.

문수백, 변창진(2003). K-ABC 교육·심리측정도구(Korean-Kaufman assessment battery for children). 서울: 학지사.

변순용, 손경원(2011). 다문화가정 아동의 도덕적 실태 분석과 다문화적 덕목의 필요성-다문화 가정 아동의 사회. 정서적 유능성을 중심으로. 윤리교 육연구, 26, 137-16.

안정숙, 전성균, 한준규, 노경선, Goodman, R. (2003). 한국어판 강점. 난점 설문지(Strengths and Difficulties Questionnaire) 개발. 신경정신의학, 42(1), 141-147.

이승연, 최정아(2012). 다문화 가정 유아의 보호요인과 행동문제에 대한 부모와 교사의 평가 비교. 교육과학연구, 43(3), 59-84.

이은주, 오소정(2019). 화용언어능력과 정서/행동문제와의 관련성-초등학교 3 학년 아동을 중심으로. Communication Sciences \& Disorders, 24(4), 906-924.

임은주, 정문자(2010). 의사소통장애 아동의 문제행동에 영향을 미치는 요인. 언어청각장애연구, 15(1), 79-93.

최윤정, 김이선, 선보영, 동제연, 정해숙, 양계민, 이은아, 황정미(2019). 2018년 전국 다문화가족실태조사 연구. 한국여성정책연구원.

한지윤, 임동선(2018). 부모 보고형 아동 언어 능력 평가도구(KBPR)의 표준화를 위한 예비연구. 언어치료연구, 27(2), 69-84.

\section{ORCID}

양윤희(제1저자, 연구원 https://orcid.org/0000-0003-3240-5996); 임동선(교신저자, 교수 https://orcid.org/0000-0001-8254-9504) 